\title{
Introduction to Forum: Graceful Eldercare
}

\author{
Michael S. Koppel • Janet E. Schaller
}

Published online: 27 November 2010

(C) Springer Science+Business Media, LLC 2010

These writings dedicated to Professor William M. Clements, Professor Emeritus of Pastoral Care and Counseling at Claremont School of Theology (CST), started as a collegial conversation between the two of us (Michael and Janet). Our dialogue expanded to include other CST graduates who had studied with Bill Clements. This broadening of the conversation circle reflects the generative spirit of Bill who for almost two decades mentored students in graduate theological education at CST.

Bill Clements shared willingly of his own strengths and challenges, never hiding behind an academic façade of pretense and perfection. Perhaps because of his own authenticity and self-acceptance, Bill easily accepted other people just as they are. Through his presence, Bill encouraged students to reflect creatively and to take risks in their academic and ministerial vocations. Bill followed his own advice by initiating a supervisory education track in the clinical training of the Ph.D. program in Pastoral Care and Counseling at Claremont. The vision and good sense of Bill Clements represent legacies that inhabit the teaching and care ministries of his students. Articles in this journal edition address ministry with the aging, expanding the conversation on a topic that captured Professor Clements' attention for some 30 years of his career.

We chose the title "Graceful Eldercare" to express our conviction that caregivers are called to honor the integrity and wholeness of each person along life's journey, older adults being no exception. Carroll Saussy's (1998) rendering of grace, "the action of God's spirit within, luring beings to live as fully and generatively as possible," names our intention for care (p. 14). The contributors to this issue show manifold ways of exhibiting grace in ministries with older adults.

\footnotetext{
M. S. Koppel $(\square)$

Pastoral Theology and Congregational Care, Wesley Theological Seminary, 4500 Massachusetts Avenue, NW Washington DC, DC 20016, USA

e-mail: mkoppel@wesleyseminary.edu

J. E. Schaller

Pastoral Care and Counseling, Memphis Theological Seminary, 168 East Parkway S, Memphis, TN 38104, USA

e-mail: jschaller@MemphisSeminary.edu
} 


\section{Wisdom and fragility}

Life is fragile at any age. Yet, many people, beginning in early old age, perceive body changes as negative. Frustration can ignite when doing tasks that had previously been simple, such as opening jar tops. Body parts gradually show signs of decreased strength and/or slowing down. A felt sense of fragility emerges in other ways: a heightened emotional sensitivity to the ebbs and flows of relationships; insecurity as financial circumstances change; and dislocation experienced through hospitalization or institutionalization. As editors we link fragility with wisdom, a refined knowledge that has depth, breadth, and soul. Wisdom may emerge from or be called forth in the cauldron of life's trials.

The tension-filled arena of wisdom and fragility frame the articles here that focus on persons who are homebound, or dying, or in counseling. Janet Schaller offers a window into the lives of several older women through the details and analysis of their conversations. Schaller makes acquaintance with these older women who must stay close to home and in so doing invites everyone to share in the gift of relationship. Jacqueline Chase develops the metaphor of sanctuary to describe pastoral caregiving with people who are dying. Chase shows how wisdom is enacted as care providers cultivate an attitude of protective holding in order to honor and respect a dying person's deepest needs and desires. Christine Reimers analyzes caregiving vignettes with women in the early stage of older adulthood who suffer with emotional frailty, relational breaks, and economic insecurities. Reimers emphasizes the practical wisdom of broadening care to include both parish pastor and pastoral counselor.

\section{Congregations and community}

Aging in isolation is harmful for psychological and spiritual health, and reflects a tragic flaw of modern life. Through larger ecclesial and social networks, older and younger generations alike can teach and support one another in aging. Ministries of care rightfully draw on the resources that healthy communities and congregations have to offer elderly persons. Older adults offer blessing to communal life as they continue to contribute in meaningful ways, even when participation requires adjustments for everyone.

Articles in this section address healthful aging, and identify ways that congregations and communities influence self-understanding constructively by challenging unhelpful stereotypes. Gloria Johnson highlights the invaluable role of older adults in shaping a community's ethical and theological values. Johnson conducts interviews of AfricanAmericans in the small southern town of Attalla, and shows through critical story reflection how the values of one generation affect another. Cynthia Elledge-Volker argues that the bodily changes of age do not necessarily need to fuel a diminished sense of self. ElledgeVolker challenges communities and the elderly themselves to participate in practices that support positive potential of aging. Kwanghee Park introduces a holistic model of care, based on Traditional Chinese Medicine. Park charts the historical and philosophical roots of this art to develop beneficial spiritual recommendations for Asian persons and congregations.

\section{Story and spirituality}

Personal narratives are the building blocks of meaning for people of any age, including older adults. The meanings people claim in their stories may be discovered in the 
construction, reconstruction, and retelling of these narratives. People sometimes tell stories as if they have included all episodes into a seamless narrative while, in general, each person actually builds a narrative by selecting experiences that conform to an already established storyline. Even so, self-narratives are rarely static and may change when confronted with new or reviewed life experiences.

The articles in this section as a whole examine the complex interconnection between story-telling and spirituality or need to make meaning. Jill Snodgrass and Siroj Sorajjakool point out that modifications to meaning-making, a component of spirituality, may occur as a response to life events. Snodgrass and Sorajjakool suggest that the ability to review and rewrite one's life story reflects generative aging. Several of the authors have been students in or teaching assistants for Bill Clements' course on spiritual autobiography groups, including Mary Clark Moschella. In her essay, Moschella outlines life review gains for older adults when undertaken as part of a small group experience. She suggests that life review can be used in an interview setting with supportive family and congregation members. Dagmar Grefe also expands the use of spiritual autobiography to intercultural and intergenerational groups. Grefe argues that cross-group story sharing creates opportunities for greater understanding of others while diminishing cultural stereotypes. Story-telling can be provoked through human and non-human partners. Michael Koppel creatively builds on the notion of a ministry of presence to include animal and inanimate companions - dogs, cats, and even teddy bears - as assistants in care with older adults. Koppel illustrates the many ways that animals and objects stimulate healing conversation in situations of care.

True to the spirit of Professor Clements, the articles in this volume integrate clinical wisdom, personal insight, psycho-social theory, and theological reflection. These essays also reflect Professor Clements' deep intellectual commitment to draw connections between theory and people's real life celebrations and struggles. As editors, we intend this volume to serve as a resource for pastors, care educators, and laity who care with and for persons in life's fourth quarter and their families. The volume speaks to a pressing need for gracefilled, expanded, and creative eldercare as baby boomers age and active parishioners reach their seventh decade of life and beyond.

\section{Reference}

Saussy, C. (1998). The art of growing old: A guide to faithful aging. Minneapolis: Augsburg Fortress. 